\title{
Е.Н. Кульков*
}

\section{ФИНЛЯНДИЯ В ВОЙНЕ ПРОТИВ СССР 1941-1944}

22 июня 1941 г. Германия напала на Советский Союз. В речи по радио Гитлер заявил, что немецкие войска «в союзе со своими финскими товарищами» ведут борьбу на берегах Северного Ледовитого океана. ${ }^{1}$ Финский президент Р. Рюти поспешил опровергнуть это заявление. Он заверил представителей зарубежной печати в том, что «только нападение извне может заставить Финляндию отказаться от нейтралитета». ${ }^{2}$ Оба эти заявления не отражали истинного положения дел. Находившиеся в тот день на севере у океанских берегов немецкие и финские войска еще только развертывались для перехода в наступление. Что касается фринского руководства, то оно заявлением о нейтралитете пыталось замаскировать находившуюся на завершающей стадии подготовку Финляндии к вступлению в войну с СССР.

Германо-фринляндское военное сотрудничество на антисоветской основе началось после того, как 31 июля 1940 г. на совещании высшего командования вермахта, принявшем решение о подготовке нападения на СССР, Финляндия была отнесена к числу вероятных союзников Германии. ${ }^{3}$ При этом в Берлине учитывалось стремление финской правящей верхушки взять реванш за советско-фринляндскую войну 19391940 гг., а также давние притязания наиболее агрессивно настроенной части фринских политических деятелей на советскую Карелию. В августе 1940 г. по указанию Гитлера начались поставки немецкого вооружения в Финляндию. Затем 12 и 22 сентября Германия подписала с Финляндией два соглашения, на основе которых она получила право на транзит через финскую территорию своих войск и военных материалов в оккупированную Норвегию. ${ }^{4}$ Под прикрытием этих соглашений началось превращение

\footnotetext{
* Кульков Евгений Николаевич, кандидат исторических наук, старший научный сотрудник Института всеобщей истории РАН.
} 
Финляндии в плацдарм для вторжения на советскую территорию с северо-запада. Начиная с осени 1940 г. в различных вариантах плана нападения на СССР, разрабатывавшихся германскими военными штабами, важное место отводилось германо-финляндскому сотрудничеству в проведении операций по захвату Мурманска и Ленинграда. В ходе переговоров с представителями фринского военного командования немецкое руководство к зиме 1940/41 г. полностью убедилось в том, что его расчет на активное участие Финляндии в предстоящем походе на восток оказался верным. В окончательном варианте плана войны против Советского Союза, утвержденном Гитлером 18 декабря 1940 г. в директиве № 21 под условным названием «Барбаросса», указывалось, что Финляндия должна прикрывать сосредоточение и развертывание немецких войск, следующих из Норвегии через ее территорию к советской границе, а также вести боевые действия совместно с этими войсками. На Финляндию предполагалось также возложить ответственность за захват советской военно-морской базы на полуострове Ханко. ${ }^{5}$

В конце мая-начале июня 1941 г. во время переговоров между представителями высшего военного командования Германии и Финляндии были подробно обсуждены задачи Финляндии в завершении подготовки и ведении войны против СССР. Финская сторона взяла на себя следующие обязательства:

1. Обеспечить прикрытие сосредоточения войск немецкой армии «Норвегия» на севере Финляндии в районе Петсамо и Рованиеми. Передать в подчинение командования этой армии один финский армейский корпус в составе двух дивизий.

2. Выставить 6 финских дивизий на своей юго-восточной границе в качестве первого эшелона для наступления вдоль западного или восточного побережья Ладожского озера в южном направлении с целью соединения с немецкими войсками группы армий «Север» после того, как последние фрорсируют Западную Двину и перейдут в наступление на Ленинград. Подготовить еще 7 финских дивизий для участия в операции по блокированию Ленинграда с юга и севера.

3. Осуществлять блокаду с моря и суши советской военно-морской базы на полуострове Ханко до тех пор, пока она не будет атакована и захвачена переброшенной из Германии в Финляндию немецкой 163-й дивизией.

4. Предоставить аэродромы Финляндии в распоряжение германских ВВС, предназначенных для поддержки наступления сухопутных войск и минирования с воздуха Невы и Беломорско-Балтийского канала.

5. С 10 по 13 июня провести мобилизацию пограничных войск; с 15 по 20 июня привести в боевую готовность фринские ВВС, ВМС и береговую артиллерию.

6. Перед началом войны против СССР оказать содействие германским ВМС в установке минных заграждений с целью запереть основные силы советского Балтийского фрлота в Финском заливе.

7. 28 июня завершить подготовку к переходу в главное наступление финских войск в районе Ладожского озера. ${ }^{6}$

Финское руководство, как отмечал начальник генерального штаба сухопутных войск Германии генерал-полковник Ф. Гальдер, было «готово к любому сотрудничеству» в предстоящей войне против Советского Союза. Объяснялось это, прежде всего тем, что оно к тому времени уверовало в непобедимость германских вооруженных сил, покоривших в ходе предшествовавших молниеносных военных кампаний почти всю Европу. По мнению фринских генералов, Германия должна была разгромить СССР в течение шести недель, в крайнем случае, не позднее чем через четыре месяца. ${ }^{7}$ Это мнение разделяло и политическое руководство Финляндии. За сотрудничество в разгроме СССР оно рассчитывало получить поддержку Германии в осуществлении замыслов о создании «Великой Финляндии» за счет советских земель. 14 июня 1941 г. фринское руководство направило в Берлин меморандум. В нем выдвигались претензии на ревизию финляндско-советской границы, установленной Московским мирным договором от 12 марта 1940 г., содержалось требование включить в состав Финляндии советскую Карелию и Кольский полуостров, а также «обосновывался» план насильственного изгнания русских из подлежащих захвату Финляндией советских территорий. После разгрома СССР их предполагалось заселить ингерманландцами, карелами, вепсами, черемисами и «другими финскими соплеменниками», с давних пор проживавшими в Ленинградской, Калининской и Новгородской областях России. ${ }^{8}$ 
Политическое и военное руководство Финляндии, вступив в сговор с германским агрессором, ставило перед собой цель скрыть этот фракт от мировой общественности и фринского народа. Поэтому в ходе германо-финляндских переговоров, проходивших в Хельсинки в начале июня 1941 г., оно заранее начало подыскивать аргументы в пользу версии о том, что Финляндия начнет "оборонительную», а не захватническую войну. Начальник генерального штаба финляндских вооруженных сил генерал Э. Хейнрикс 5 июня заявил представителями германского командования, что положение в Финляндии не такое простое, как, наверное, думают в Германии, поскольку ее население более чем на $40 \%$ состоит из социалистов, которые не одобрили бы агрессию. «Поэтому Финляндия,- говорил он,- приветствовала бы, если бы немецкие операции начались раньше, и надеется быть спровоцированной». ${ }^{9} 16$ июня Маннергейм подтвердил желание финского руководства, чтобы главные операции финских войск начались через несколько дней после перехода в наступление немецкой армии «Норвегия». ${ }^{10}$ В Хельсинки рассчитывали, что в ответ на выдвижение к советской границе войск этой армии командование Красной Армии примет контрмеры, которые можно будет истолковать как нападение на Финляндию и использовать в качестве повода для объявления войны Советскому Союзу.

Во время переговоров в Хельсинки начались последние германо-финляндские приготовления к агрессии. 5 июня из Осло и Штеттина вышли транспортные суда. На их борту находился первый эшелон войск 36-го армейского корпуса армии «Норвегия». Через три дня началась их выгрузка в северо-западных фринских портах. Уже 14 июня на севере Финляндии высадилось более 30,6 тыс. немецких солдат. Оттуда они направлялись в район Рованиеми. С 10 июня в Финляндии началась мобилизация в пограничных войск. 11 июня под Рованиеми был создан командный пункт немецкой армии «Норвегия». 13 июня в Хельсинки из Берлина прибыл в качестве начальника германского штаба связи при финском главном командовании генерал В. Эрфурт. 16 июня финское командование получило сообщение из Берлина о том, что в ближайшее время Германия выступит против СССР. ${ }^{11}$ На следующий день в Финляндии началась всеобщая мобилизация. 3-й финский армейский корпус в составе двух дивизий и батальон пограничной охраны «Петсамо» были переданы в распоряжение командования армии «Норвегия». Для ведения боевых действий против СССР маршал Маннергейм оставил под своим командованием 14 дивизий и три бригады. ${ }^{12}$ В ночь с 21 на 22 июня немецкие корабли с помощью фринских лоцманов поставили минные заграждения у выхода из Финского залива. Ночью 22 июня финские пограничники открыли границу с Норвегией немецкому горному корпусу «Норвегия». Согласно плану, его войска на следующий день сосредоточились в Петсамо. На рассвете 22 июня, незадолго до начала нападения Германии на СССР, группа немецких самолетов, вылетевшая из Восточной Пруссии в сопровождении финских штурманов, установила магнитные мины в Кронштадтской бухте, а затем приземлилась на финский аэродром для дозаправки горючим. Тогда же два немецких самолета «Хе-115» высадили в советской Карелии финскую диверсионную группу, которая после неудачной попытки взорвать шлюзы БеломорскоБалтийского канала взорвала рельсы на одном из участков Мурманской железной дороги. ${ }^{13}$ Днем 22 июня финское политическое руководство заявило о своем мнимом нейтралитете, рассчитывая таким образом скрыть свое участие в развязывании войны против СССР.

СССР пытался доступными ему средствами воспрепятствовать вступлению в войну Финляндии. 22 июня нарком обороны маршал С.К. Тимошенко отдал войскам Ленинградского военного округа строгий приказ не допускать никаких действий, которые могли бы привести к обострению советско-финляндских отношений. ${ }^{14}$ Такие же приказы были отданы советским Северному и Балтийскому Краснознаменному флотам. 23 июня советский министр иностранных дел В.М. Молотов заявил финскому посланнику в Москве П. Хюннинену, что СССР не имеет каких-либо претензий к Финляндии и не стремится нарушить ее самостоятельность или территориальную целостность. ${ }^{15}$ Между тем с каждым днем советскому руководству становилось все яснее, что заявление финского правительства о нейтралитете продиктовано лишь тактическими соображениями, что на самом деле оно уже сотрудничает с Германией. Тем не менее, оставался в силе приказ, согласно которому советские пограничники могли вступать в бои только в том случае, если финны перейдут в наступление. Лишь 25 июня 
советские ВВС нанести удары по скоплениям немецких самолетов на фринских аэродромах, с которых они совершали боевые вылеты против советских войск. Одновременно Московское радио сделало сообщение о том, что действия советской авиации направлены не против Финляндии, а против находящихся на ее территории вооруженных сил Германии. Эта по существу оборонительная акция советских летчиков была использована финским руководством 26 июня 1941 г. в качестве повода для официального заявления о том, что СССР якобы напал на Финляндию. ${ }^{16} \mathrm{C}$ того дня финское правительство в своей пропаганде стало утверждать, что оно ведет якобы «войну-продолжение» оборонительной «Зимней войны» 1939-1940 гг.

29 июня 1941 г. начали боевые действия выдвинувшиеся к советской границе соединения немецкой армии «Норвегия». На северо-западе Финляндии в тот день перешел в наступление немецкий горный корпус «Норвегия». Он должен был захватить Мурманск с его незамерзающим портом и тем самым лишить Советский Союз связи с Северной Атлантикой, имеющей для него важное стратегическое значение. 1 июля примерно в 400 км южнее двинулся на восток немецкий 36-й армейский корпус. Он должен был перерезать Мурманскую железную дорогу в районе Кандалакши. Одновременно с ним выступил финский 3-й армейский корпус. Его цель заключалась в выходе к Белому морю в районе Лоухов и Кеми. Ни одному из этих трех корпусов не удалось выполнить поставленных перед ними задач. Противостоящие им войска советской 14-й армии упорно обороняли каждую пядь своей земли. Они нанесли существенный урон противнику. По этой причине Гитлер 22 сентября был вынужден согласиться с прекращением наступления на Мурманск. 10 октября он отдал распоряжение о переходе к обороне всем войскам армии «Норвегия». К тому времени им удалось продвинуться на советскую территорию лишь на незначительное расстояние. От Мурманска их отделяло от 50 до 60 км, от Кандалакши - 60 км, от Лоухов - 40 км. ${ }^{17}$ Все их последующие попытки продвинуться на восток не имели успеха.

В конце ноября - начале декабря между командованием армии «Норвегия» и Маннергеймом проходило обсуждение вопроса о возобновлении наступления на Кандалакшу. Маннергейм сумел убедить командование армии «Норвегия» в том, что в «сложившейся обстановке» наступление на Кандалакшу не имеет перспектив на успех, что «лучше в начале марта провести концентрическое наступление на Беломорск с целью перерезать там Мурманскую железную дорогу и создать исходный пункт для дальнейших операций». Наступление на Беломорск должны были вести фринские войска, усиленные одной немецкой дивизией из Германии, в то время как армия «Норвегия» должна была сковать противостоявшие им советские соединения в районе Саллы и в Заполярье. В связи с подготовкой наступления на Беломорск Маннергейм потребовал, чтобы армия «Норвегия» передала в его подчинение участок 3-го финского корпуса и вернула в состав этого корпуса одну фринскую дивизию и два пулеметных батальона, которые перед нападением на СССР были включены в состав 36-го немецкого корпуса. ${ }^{18}$ Главное командование сухопутных войск Германии в январе 1941 г. одобрило замысел наступления на Беломорск и возвратило под командование Маннергейма практически все фринские войска, которые ранее были включены в состав армии «Норвегия». В связи с изменением структуры этой армии и стоящих перед ней задач она была переименована в армию «Лапландия».

Далеко не так, как планировало немецкое и финское командование, развивались события в районе Ленинграда и Ладожского озера. 8 июля 1941 г. войска немецкой группы армий «Север» вышли к Чудскому озеру. Ее командование приняло решение развернуть 10 июля наступление на Ленинград между Чудским и Ильменским озерами силами 4-й танковой группы. В связи с этим главное командование сухопутных войск Германии приняло решение об одновременном переходе в наступление финских войск вдоль восточного побережья Ладожского озера. Через германский штаб связи в Хельсинки это решение было доведено до К. Маннергейма. 10 июля по его приказу перешла в наступление развернутая северо-восточнее Ладожского озера фринская Карельская армия. Входивший в ее состав 6-й армейский корпус (две дивизии и одна бригада) двинулся вдоль восточного берега Ладожского озера в южном направлении. Он должен был выйти к реке Свирь, форсировать ее в районе Лодейного поля и соединиться там с наступавшими с запада немецкими войсками. Развернутый справа от него 7-й армейский корпус (две дивизии) Карельской армии перешел в наступление на 
Сестрорецк с целью овладеть этим городом и северо-восточным побережьем Ладожского озера. На левом фланге Карельской армии в направлении на Петрозаводск наступала финская группировка в составе двух подвижных бригад. На всех трех направлениях фринские войска имели многократное превосходство в силах над противостоявшими им войсками 7-й советской армии. Первоначально финнам сопутствовал успех, в то время как войска группы армий «Север», с которыми 6-й армейский корпус должен был соединиться на р. Свирь, через два дня после перехода в наступление оказались скованными советскими войсками в районе Луги. Финские войска по мере продвижения вглубь советской Карелии также встречали все более возраставшее сопротивление советских войск. В середине июля немецкое командование, заинтересованное в том, чтобы войска фринской Карельской армии как можно скорее достигли р. Свирь, передало ей прибывшую из Германии через Швецию в Финляндию 163-ю дивизию, которую первоначально планировалось использовать для захвата полуострова Ханко. Она поступила в распоряжение командования финской Карельской армии в неполном составе: один из трех ее полков был ранее передан 36-му немецкому корпусу, наступавшему на кандалакшском направлении. Этой дивизии были приданы две подвижные финские бригады и поставлена задача по обеспечению левого фланга 6-го армейского корпуса, наступавшего вдоль восточного берега Ладожского озера. Но она не справилась с этой задачей. Советские войска продолжали сильные атаки левого фрланга финской Карельской армии, в результате чего быстро росли ее материальные и человеческие потери. Это вынудило Маннергейма 23 июля дать приказ 6-му армейскому корпусу прекратить наступление. В тот день от р. Свирь его отделяло 60 км. Вскоре остановились также финские войска, наступавшие на петрозаводском направлении. ${ }^{19}$

30 июля Гитлер приказал войскам группы армий «Север» возобновить наступление на Ленинград. На следующий день по требованию немецкого командования Маннергейм отдал приказ войскам 2-го финского корпуса (три дивизии), развернутым у советской границы северо-западнее Ладожского озера, наступать на Ленинград с севера. Но 2-го августа он отклонил требование немцев возобновить наступление финских войск восточнее Ладожского озера на том основании, что к тому времени 6-й армейский корпус еще не оправился от понесенных ранее потерь. Наступление 2го финского корпуса на Карельском перешейке развивалось медленно. Прикрывавшие ленинградское направление с севера войска советской 23-й армии оказывали ему упорное сопротивление. В конце августа в наступление на Ленинград с севера включился также фринский 4-й армейский корпус. Лишь благодаря большому превосходству в силах после кровопролитных боев финнам 1 сентября удалось выйти к советскофинляндской границе 1939 г. и в ряде мест несколько далее ее. Здесь советские войска, опираясь на старые долговременные укрепления Карельского укрепленного района, сумели создать прочную оборону. 20 сентября фронт на северных подступах к Ленинграду стабилизировался вплоть до июня 1944 г.

С первых дней участия Финляндии в антисоветской агрессии финское военное командование начало понимать, что оно просчиталось в оценке боеспособности Красной Армии. Маршал К. Маннергейм отмечал, что он столкнулся с «трудностями, которые всюду оказались более значительными, чем можно было бы предположить». ${ }^{20}$ По этой причине он дважды отклонял выдвинутый 22 августа 1941 г. верховным главнокомандованием вермахта план, предусматривавший участие финских войск, наступавших на Карельском перешейке, в штурме Ленинграда с севера.. ${ }^{21}$ Вместе с тем, фринские войска оказывали немалую услугу нацистам тем, что активно содействовали установлению блокады города и связывали к северу от него крупные силы советских войск.

4 сентября 1941 г. финские войска возобновили наступление восточнее Ладожского озера. На этот раз им удалось 11 сентября выйти к р. Свирь и захватить плацдарм на ее южном берегу. 8 сентября немецкие войска овладели Шлиссельбургом и блокировали Ленинград с юга. От фринских войск, блокировавших город с севера, их отделяло по прямой линии 40-70 км, а от фринских войск на р. Свирь примерно 180 км. Во второй половине октября войска группы армий «Север» развернули наступление на Тихвин с целью пробиться к финским войскам на р. Свирь. С большими потерями только 8 ноября немецкому 39-му корпусу удалось вступить в этот город. Казалось, что 
соединение немецких и фринских войск уже не за горами. Однако этого не случилось. Наступательные возможности немецких войск, захвативших Тихвин, были исчерпаны. Маннергейм, обещавший развернуть наступление фринских войск со свирского плацдарма с целью соединения с ними, отказался от этого намерения. Причиной тому были сильные постоянные контратаки советских войск. 9 декабря они освободили Тихвин. Рукопожатия немецких и финских войск на р. Свирь так и не состоялось. Попытка создать второе блокадное кольцо вокруг Ленинграда потерпела крах. Вскоре полностью были исчерпаны наступательные возможности финских войск в северной и средней части советской Карелии. В середине декабря они были скованы советскими войсками на рубеже западнее Кандалакши, Лоухов, Ухты, Ругозера, станции Масельская и у южного участка Беломорско-Балтийского канала. На полуостров Ханко фринские войска вступили в начале декабря, после того как эвакуировался гарнизон располагавшейся там советской военно-морской базы. В конце 1941 г. вооруженные силы Финляндии, потеряв только убитыми 25 тыс. солдат и офицеров, перешли к стратегической обороне на всех участках занимаемого ими фронта. ${ }^{22}$

Во время продвижения финнов вглубь советской Карелии ее мирное население в основной своей массе (около 430 тыс. человек) эвакуировалась в Беломорск, Вологодскую, Архангельскую, Молотовскую, Кировскую и Свердловскую области, а также в республику Коми. Под фринской оккупацией осталось 85,7 тыс. человек. Из них около 44 тыс. были русскими, 39 тыс. фриннами, карелами и вепсами, а остальные других национальностей. ${ }^{23}$ По отношению к этому населению фринское политическое и военное руководство проводило политику, которая строилась на том, что после победоносного окончания войны советская Карелия будет присоединена к Финляндии. Советских карелов, фриннов и вепсов оно рассчитывало перевоспитать в духе лояльных граждан будущей «Великой Финляндии», а русскую часть населения переселить с согласия гитлеровского правительства в Россию, после того как она будет захвачена Германией. Отношение фринской военной администрации к русским было враждебным. Примерно половина их (22 тыс. человек) была заключена в концентрационные лагеря, где они находились на положении военнопленных. В этих концлагерях в 1942 г., по финским данным, только от голода умерло 3,5 тыс. человек. Положение остальной части русского населения было не намного лучше. Их насильственно переселяли в отдельные от карелов деревни и держали там под неусыпным контролем. Они гораздо хуже, чем остальная часть населения, снабжались продовольствием. За одну и ту же выполняемую работу они получали гораздо меньшую заработную плату. С карелами же финские оккупанты заигрывали, пытаясь представить себя «освободителями». Карелам было разрешено брать для обработки земельные участки, которые они, согласно обещаниям оккупантов, после разгрома СССР должны были перейти в их частную собственность. Тех карелов, которые выражали свое недовольство оккупационным режимом, помещали в специально созданный для них концентрационный лагерь. ${ }^{24}$

Жестокость фринской оккупационной политики, особенно по отношению к русской части мирного населения, вызывала возмущение и протест во всех странах антигитлеровской коалиции. Однако эта политика оставалась практически неизменной до осени 1943 г., т.е. до тех пор, пока фринское руководство под влиянием побед Красной армии на советско-германском фронте окончательно не убедилось в нереальности плана создания «Великой Финляндии». С тех пор оно постепенно стало отказываться от политики разделения населения оккупированной Карелии по национальностям. Тем не менее, ко времени выхода Финляндии из войны на стороне Германии в сентябре 1944 г. в концлагерях оставалось еще до 15 тыс. мирных русских граждан. ${ }^{25}$

С начала войны против СССР финское политическое руководство было уверено в том, что германскому вермахту, стремительно продвигавшемуся летом 1941 г. на восток, вот-вот удастся разгромить Красную Армию. Поэтому в августе 1941 г. оно отвергло поступившее в Хельсинки через посредничество США предложение Москвы заключить новый советско-финляндский мирный договор, в котором были бы сделаны «некоторые территориальные уступки Финляндии». ${ }^{26}$ Великобритания и США осенью 1941 г. предпринимали неоднократные попытки склонить фринское правительство выйти из нацистской военной коалиции и тем самым облегчить тяжелое положение мирного населения блокированного Ленинграда. Но правители в Хельсинки всячески уклонялись от обсуждения этого вопроса. Они все еще надеялись, что союз с Германией от- 
кроет им возможность реализовать замысел о создании «Великой Финляндии». Поэтому финское политическое руководство заискивало перед гитлеровским правительством, стремилось всячески ему угодить. 26 ноября1941 г. оно подписало протокол о присоединении к Антикоминтерновскому пакту. За проявленную таким способом антисоветскую солидарность с нацистской Германией и другими ее союзниками ему удалось заручиться согласием Гитлера на включение после победоносного завершения войны в финское «жизненное пространство» Кольского полуострова. ${ }^{27}$

На отказ Финляндии порвать военно-политическое сотрудничество с Германией английское правительство 6 декабря 1941 г. отреагировало объявление ей войны. ${ }^{28}$ В связи с этим и СССР ужесточил свою позицию в вопросе, касающемся условий будущего мирного урегулирования с Финляндией. 16 декабря в Москве было решено не делать каких-либо территориальных уступок Финляндии и настаивать на полном восстановлении советско-финляндской границы, установленной мирным договором между СССР и Финляндией от 12 марта 1940 г. $^{29}$

Переход в начале декабря 1941 г. к позиционной войне на фринляндском участке фрронта вынудил маршала Маннергейма более критично относиться к прежним планам ведения боевых действий. Он пришел к выводу, что при сложившемся соотношении сил возобновление наступательных действий финских войск на Кандалакшу не будет иметь успеха. Вместо этого он предложил командованию немецкой армии «Норвегия» провести в начале марта 1942 г. концентрическое наступление на Беломорск «с целью перерезать там Мурманскую железную дорогу и захватить исходную позицию для дальнейших операций». Для того чтобы обеспечить успех этого наступления, он потребовал вернуть под его командование финские соединения и части 3-го и 36-го армейских корпусов. Немецкие войска армии «Норвегия» во время проведения этой операции должны были лишь сковывать противостоявшие им советские войска с тем, чтобы воспрепятствовать их переброске под Беломорск с целью укрепления обороны города. Этот план, предложенный Маннергеймом, был полностью поддержан командованием армии «Норвегия». В связи с тем, что принятие плана Маннергейма привело бы сокращению численности войск армии «Норвегия» и занимаемого ими участка фронта, ее командование хотело изменить название армии. Она должна была бы называться армией «Лапландия». Этот план, предложенный Маннергеймом, был представлен командованием армии «Норвегия» на рассмотрение в штаб верховного главнокомандования вермахта. Оттуда он 12 декабря 1941 г. был направлен также на рассмотрение в генеральный штаб сухопутных войск. ${ }^{30}$ Там он был одобрен в начале января 1942 г. Таким образом, Маннергейму удалось вернуть под свое командование практически все финские войска, переданные в июне 1941 г. немецкому командованию. Что же касается развертывания наступления на Беломорск, то эта затея осталась лишь на бумаге. Весной 1942 г. внимание немецкого командования было сосредоточено на тяжелом положении немецких войск под Москвой, а внимание фринского руководства - на создавшемся тяжелом положении с рабочей силой. Летом 1941 г. в вооруженные силы Финляндии было призвано более 600 тыс. человек, что составило около 17 процентов всего населения страны. ${ }^{31}$ В начале войны финское руководство не задумывалось над тем, как это скажется на экономике страны. Оно рассчитывало на молниеносный и победоносный исход войны. Но война приняла затяжной характер, и встал вопрос о том, как обеспечить промышленность и сельское хозяйство достаточным количеством рабочих рук. Президент Финляндии Р. Рюти выяснил, что только для успешного проведения весенне-полевых работ придется пойти на сокращение личного состава вооруженных сил как минимум на 10 процентов. 6 феевраля 1942 г. фринский военный атташе в Берлине полковник В. Хорн поставил в известность об этом главное командование сухопутных войск Германии. При этом он подчеркнул, что, если сокращение не будет проведено, то в Финляндии разразится голод, и тогда она уже не сможет вести войну. Кроме того, он указал, что финское руководство понимает, что сокращение вооруженных сил может привести к ослаблению финского фронта, и поэтому рассчитывает на то, Германия увеличит численность ее войск на севере страны. ${ }^{32}$ Весной 1942 г. численность фринляндских вооруженных сил в связи с проведенной частичной демобилизацией сократилась не менее чем на 100 тыс. человек. Восполнить убыль войск на финском фронте за счет новых немецких соединений оказалось невозможным в виду того, что они были необходимы для восполнения потерь, которые понес вермахт 
в борьбе против наступавшей с января до апреля Красной Армии на советско-германском фронте, простиравшемся от Балтики до Черного моря. Ни о каком наступлении на Беломорск не могло уже быть и речи.

После стратегического поражения вермахта в битве под Москвой у фринской правящей верхушки появились первые сомнения в осуществимости планов немецкого командования уничтожить Ленинград. Финский президент Р. Рюти в мае 1942 г. начал вести разговоры о целесообразности после войны объявить Ленинград «свободным городом наподобие Данцига». Управление городом, по его мнению, должна была бы взять международная комиссия, в которой участвовала бы и Финляндия. ${ }^{33}$ Что касается Маннергейма, то у него усиливались сомнения относительно способности Германии одержать победу в войне против СССР. По его мнению, принятый Гитлером в апреле 1942 г. план, согласно которому летом в ходе нового стратегического наступления на южном крыле советско-германского фронта немецкие войска должны были захватить нефтеносные районы Кавказа, а затем провести операцию с целью захвата Ленинграда, был заранее обречен на провал. Под сильным давлением со стороны немецкого военного командования он все-таки дал согласие на «лишь очень скромное» участие фринских войск в запланированном германским генеральным штабом на сентябрь штурме Ленинграда. ${ }^{34}$ Однако этот штурм не состоялся. В ходе Синявинской операции советских войск Волховского и Ленинградского фронтов (19 августа-19 октября 1943 г.) немецкое командование было вынуждено отказаться от второй попытки захватить и уничтожить Ленинград: предназначавшиеся для этой операции немецкие дивизии пришлось использовать для удержания обороны, в ходе которой они понесли большие людские и материальные потери.

19 ноября 1942 г. Красная Армия перешла в контрнаступление под Сталинградом. Это событие заставило финское правительство задуматься о выходе из войны. 1 декабря премьер-министр Ю. Рангель обратился к И. Риббентропу с вопросом, как тот отнесся бы к тому, что его правительство вступило бы в мирные переговоры с советским правительством. Риббентроп ответил, что он против установления финским правительством каких бы то ни было контактов с Москвой, так как они могли бы быть восприняты там как «признак слабости» Финляндии. ${ }^{35}$ После этого фринское правительство отказалось от намерения установить контакт с Москвой, но лишь до более подходящего момента.

В финской газете «Хелсингин Саномат» от 16 января 1943 г. была опубликована статья одного ее внештатного сотрудника о начальнике генерального штаба сухопутных войск Германии генерале К. Цейтцлере. В ней Цейтцлер характеризовался как «незначительный» офицер германского вермахта, который и остался бы таковым, «если бы не судьба, которая неожиданно сделала его покровителем Генриха Гиммлера». «Отставка Гальдера и назначение его преемником Цейтцлера,- утверждалось в статье,несомненно, является политикой, цель которой заключается лишь в том, чтобы усилить власть партии в вермахте. Решающим для карьеры Цейтцлера прошлой осенью стал вопрос большого стратегического значения, от ответа на который зависело, будет ли этой зимой Германия вести оборонительную или наступательную войну на Востоке. Цейтцлер считал, что наступление должно вестись и после начала зимы, и поэтому Гальдер должен был уйти в отставку. От вопроса, удастся ли Цейтцлеру, как и его знаменитому предшественнику в прошлом году, найти против новой наступательной тактики русских такую же эластичную оборонительную тактику, зависит не только судьба Германии, но и всей Европы». ${ }^{36}$

В статье отражалось неверие финской общественности в способность германского военного руководства избежать разгрома своих войск и войск европейских партнеров Германии по Пакту трех держав в развернувшемся тогда наступлении Красной Армии под Ленинградом и на громадном пространстве от Верхнего Дона до предгорий Кавказа. Статья вызвала большое недовольство в Берлине. По поводу ее опубликования германское посольство в Хельсинки заявило резкий протест финскому правительству. Финское правительство, для того чтобы уладить конфрлит, заставило главного редактора и главного цензора газеты принести извинения германскому посланнику в Хельсинки. Президент Финляндии Р. Рюти также выразил ему свое сожаление по поводу «тенденциозной» публикации о Цейтцлере. ${ }^{37}$ Вскоре, однако, выяснилось, что автор публикации был прав, когда усомнился в целесообразности смены начальника 
генерального штаба сухопутных войск Германии. Назначение Цейтцлера в конце сентября 1942 г. на пост начальника генерального штаба сухопутных войск действительно никак не способствовало улучшению управления немецкими войсками и не предотвратило их катастрофры под Сталинградом.

Финляндское руководство окончательно утратило веру в победу в войне против СССР после того, как советские войска прорвали блокаду Ленинграда под Шлиссельбургом и одержали победу в битве за Сталинград. 3 февраля 1943 г. в ставку маршала Маннергейма в Миккели прибыли президент Финляндии Р. Рюти и ряд членов правительства. На состоявшемся совещании они пришли к единодушному мнению, что «война подошла к решающему поворотному моменту и что Финляндии при первой подходящей возможности необходимо найти способ выхода из войны». ${ }^{38}$ Это мнение они скрывали от германского руководства, чтобы избежать обвинений в предательстве и т.п. Этой же точки зрения, но не тайно, а открыто, стало придерживаться и руководство Социал-демократической партии Финляндии (СДПФ), самой крупной политической партии в стране. В начале фревраля социал-демократическая пресса развернула пропаганду тезиса о том, что Финляндия якобы «не имеет ничего общего с войной между великими державами», что она является «нейтральным», «борющимся за свою государственность, демократическую самостоятельность и безопасность государством», что «финские рабочие, как и весь финский народ, за незначительным исключением, выступают за то, чтобы межгосударственные противоречия решались не только путем войны». С середины фревраля социал-демократическое руководство стало требовать создания нового правительственного кабинета, которое «в сотрудничестве с президентом было бы способно разрешить тяжелые проблемы, с которыми в ближайшее время столкнется фринская политика». ${ }^{39}$

Эти публикации в социал-демократической прессе вызывали в Берлине большое раздражение. Особенно задело Риббентропа содержание телеграммы Блюхера от 15 февраля 1943 г., в которой сообщалось следующее: «Социал-демократический партийный совет опубликовал резолюцию, в которой помимо всего прочего утверждается следующее: «Теперешняя война является продолжением Зимней войны, оборонительной борьбой Финляндии, которая была навязана фринскому народу против его воли. Борьба ведется исключительно в целях обеспечения свободы и самостоятельности страны. Финляндия не участвует в войне великих держав. То обстоятельство, что Финляндия бок о бок с Германией борется против одного и того же противника, ничего не меняет в этом фракте. Отсюда также следует, что Финляндия, когда представится удобный случай и будет гарантирована ее самостоятельность, может принять решение о своем выходе их войны. Партийный совет сожалеет, что кое-где не придерживаются последовательно этой точки зрения, а напротив, пытаются истолковывать фринские устремления во вредном для страны духе. Партийный совет ожидает, что правительство в будущем будет уделять больше внимания этим ущербным для страны явлениям с целью воспрепятствовать их распространению.

В области внешней политики партийный совет придает значение тому, чтобы не заключались сделки, опасные для самостоятельности страны, чтобы сохранялась ее хозяйственная самостоятельность. Цель внешней политики заключается в поддержании хороших отношений со всеми дружественными Финляндии государствами. По отношению к другим странам также нужно избегать высокомерных и обидных для них действий. Партийный совет особенно подчеркивает значение поддержания дружественных отношений с северными странами и США. Препятствия, которые мешают такому развитию, должны быть устранены. Отношения с Германией, само собой, разумеется, являются хорошими и корректными». ${ }^{40}$

Риббентроп был крайне недоволен, что в этой резолюции «лишь вскользь на последнем месте упоминалось об отношении Финляндии к Германии, и в то же время особо подчеркивалось значение поддержания тесных связей с северными странами и США». В беседе с финским посланником в Берлине Т. Кивимеки, состоявшейся 16 февраля 1943 г., он пытался доказать, что Германия является единственным гарантом сохранения самостоятельности Финляндии, что при любых обстоятельствах Германия с ее союзниками выиграют войну. Это свое мнение он поручил довести до сведения финского президента Рюти своему посланнику в Финляндии. ${ }^{41}$

5 марта по инициативе президента Рюти было сформировано новое правитель- 
ство. В отличие от предыдущего правительства, в него не были включены представители профашистской партии Патриотическое народное движение (ПНД). На пост министра иностранных дел, который ранее занимал германофрил Р. Виттинг, был назначен X. Рамсай, директор судоходной кампании, издавна поддерживавший хорошие связи с Западом. 22 марта Рюти и министры нового правительства приняли предложение правительства США выступить посредником в установлении контактов между Финляндией и СССР с целью завязывания мирных переговоров. ${ }^{42}$ При этом финское правительство рассчитывало на восстановление фринляндско-советской границы 1939 г. с незначительной ее корректировкой в пользу СССР на Карельском перешейке. Что касается советской Карелии, то оно было согласно вывести с ее территории свои войска, но лишь в том случае, если она будет демилитаризована, а дальнейшая ее судьба будет решена после окончания войны на мирной конференции. Президент Рюти еще в феврале 1943 г. проинформировал президента США об этих условиях. Однако в Москве об этом не было известно. 26 марта 1943 г. нарком иностранных дел СССР В.М.Молотов сообщил в Вашингтон, что Финляндия, если она хочет мира, должна разорвать отношения с Германией и добиться вывода ее войск со своей территории, отвести свои войска на границу, установленную советско-финляндским мирным договором 12 марта 1940 г., провести демобилизацию с целью сокращения вооруженных сил, а также возместить Советскому Союзу хотя бы половину ущерба, причиненного ею в ходе совместной с Германией войны. ${ }^{43}$

Советские условия мирного урегулирования с Финляндией были несовместимы с планами выхода из войны, на осуществление которых рассчитывало финское руководство. Кроме того, они показались тогда правительству США слишком жесткими. В начале апреля оно решило не доводить их до сведения фринского правительства. По этой причине произошла значительная задержка в налаживании советско-финляндских мирных переговоров.

Главным же препятствием на пути Финляндии к миру являлась Германия. Рюти и члены финского правительства испытывали большие опасения по поводу того, что гитлеровское правительство, узнав об их мирном зондаже, предпримет против Финляндии репрессивные меры. Поэтому они решили проинформировать Берлин о поступившем от США предложении о посредничестве. Маннергейм выражал надежду, что гитлеровское правительство даст согласие на выход из войны Финляндии, так как в этом случае оно могло бы перебросить находившиеся на ее территории немецкие войска, общей численностью 200 тыс. человек, на наиболее слабые участки своего Восточного фрронта. Но он ошибся.

26 марта 1943 г. Рамсай тайно от американского посольства в Хельсинки прибыл в Берлин. К тому времени германская разведка уже сообщила германскому руководству о цели визита Рамсая. Германский министр иностранных дел Риббентроп принял решение раз и навсегда положить конец разговорам о выходе Финляндии из войны. Риббентроп, желая продемонстрировать свое недовольство финнами, принял Рамсая не сразу по прибытии, а лишь на следующий день, заставив его в течение шести часов ждать в приемной. Как только Рамсай вошел в его кабинет, он сразу заявил ему, что в случае принятия Финляндией американского предложения, Германия предпримет против нее «крайние меры». Рамсай в ответ эту угрозу поспешил заверить Риббентропа в том, что, по его мнению, фринское правительство не имеет намерения принимать предложение США. После этого Риббентроп на некоторое время прервал разговор, затем вернулся и вручил Рамсаю ноту финскому правительству. В ней говорилось, что если Финляндия пойдет на заключение мира с СССР, то Германия будет рассматривать ее как предательницу со всеми вытекающими из этого последствиями. Финскому правительству предъявлялось требование закрепить германо-фринляндские союзные отношения в тайном политическом соглашении, в котором содержалось бы обязательство Финляндии «без взаимного согласия с Германией не заключать с СССР перемирия или мира», а также как можно скорее направить правительству США ноту следующего содержания: «При данных обстоятельствах фринское правительство не в состоянии принять американское предложение о посредничестве. Финское правительство полно решимости вести борьбу в защиту Финляндии до тех пор, пока не будет полностью исключена любая угроза с Востока финскому государству». 44

С этим документом Рамсай вернулся восвояси. 30 марта к нему явился герман- 
ский посланник Блюхер и поинтересовался, почему до сих пор финское правительство не направило американцам ответ, подготовленный Риббентропом. Рамсай ответил, что внешнеполитический комитет финского правительства намерен в ближайшие дни внести в него некоторые изменения, необходимые для того, чтобы избежать подозрений, что ответ составлен под давлением из Берлина. В заключение Рамсай заверил Блюхера, что текст ответа будет согласован с ним и что «о заключении Финляндией сепаратного мира за спиной Германии не может быть и речи». ${ }^{45}$ Получив эту информацию, Риббентроп дал указание Блюхеру настоятельно требовать от финских руководителей как можно скорее «устранить неясность в фринляндско-германских отношениях».

Финское правительство долго думало над тем, как не навлечь на себя еще большего гнева со стороны германского руководства и в тоже время не разрушить отношения с США своим отказом от их посредничества в установлении фринляндско-советских контактов. Наконец, выход был найден. Американское правительство, как отмечалось выше, не сообщило в Хельсинки поступившие к нему 26 марта советские мирные условия. Этим воспользовался президент Финляндии Рюти. 10 апреля он сообщил в США, что поскольку еще неизвестны условия, которые выдвинет Советский Союз, фринское правительство «не считает для себя возможным воспользоваться посредничеством США». ${ }^{46}$ В ответ на это почти весь состав американского посольства покинул Хельсинки. Многие американские государственные деятели предлагали тогда полностью разорвать дипломатические отношения с Финляндией. Президент Рузвельт отклонил их предложение, так как его принятие уменьшило бы возможности США оказывать влияние на дальнейшее развитие событий в Европе.

Между тем, общественное мнение в Финляндии все сильнее склонялось к тому, что необходимо найти пути к выходу из войны. Финское правительство, учитывая это, решило предпринять меры по созданию предпосылок для выхода из состояния войны с Великобританией. В начале апреля 1943 г. на пост финского посланника в нейтральной Швеции был назначен бывший финский посланник в Лондоне Г. Грипенберг, близкий родственник Маннергейма, женатый на уроженке США, которая после объявления Англией войны Финляндии выехала на родину. Грипенберг начал осторожно нащупывать контакты с Лондоном. В финских газетах стало уделяться повышенное внимание сообщениям о событиях в Северной Африке. Они иллюстрировались фотоматериалами о боях англичан против немецких и итальянских войск. В связи с этим, немецкий военный атташе в Хельсинки вынужден был заявить протест фринскому командованию. «Что сказали бы в Финляндии по поводу фотографий в немецкой ежедневной прессе,-говорил он,- если бы в ней изображались боевые действия русских войск против фринского фронта». ${ }^{47}$

8 мая Центральный совет профсоюзов Финляндии от имени рабочих выступил за «немедленное окончание войны», как только представится такая возможность. Он высказался за установление доверительных связей фринского народа с народами северных соседних стран, указав также, что «наш народ нельзя оторвать от соседства с Советским Союзом и побережьем Балтийского моря» и предостерег правительство от шагов, которые могли бы вынудить США разорвать с Финляндией дипломатические отношения. ${ }^{48}$

Финское правительство было вынуждено учитывать растущую волю населения к миру, а также позицию США, выступавших за разрыв фринляндско-германского сотрудничества. В тоже время оно боялось обострять отношения с Германией, требовавшей от него заключить с ней соглашение, которое официально закрепило бы германо-финляндский антисоветский военно-политический союз. Что бы избежать этого, фринское правительство прибегло к сомнительному маневру. Премьер-министр Э. Линкомиес в начале мая публично заявил, что «правительство Финляндии твердо намерено продолжать ведущуюся Финляндией войну». В Берлине сомневались в этом, так как в фринской прессе по-прежнему продолжалась дискуссия о возможности выхода Финляндии из войны.

26 мая 1943 г. Блюхер по указанию Риббентропа встретился с Рюти и в течение двух часов пытался склонить его к согласию на заключение германо-финляндского союза, направленного против СССР. Он долго говорил, что Германия при любых обстоятельствах не бросит на произвол судьбы Финляндию, которая ведет войну «ради сохранения своей самостоятельности». Поэтому ему непонятно, почему фринская пре- 
сса ведет пропаганду за выход страны из этой войны, а финское правительство вот уже как два месяца затягивает решение вопроса о заключении военно-политического соглашения, на котором настаивало германское правительство в марте 1943 г. Рюти в ответ на это заявил: «Финляндия, которая в процентном отношении потеряла людей больше, чем Германия, выполнила свой долг перед Германией и поэтому не заслуживает того, чтобы ей отвечали подозрением и требовали от нее еще и письменных заверений. На самом деле нет никаких разногласий: Финляндия продолжает войну против Советского Союза, как об этом было заявлено в недавней речи премьер-министра». Далее Рюти указал, что расстановка сил в финском парламенте такова, что нет никакой надежды на утверждение германо-финляндского соглашения, которое закрыло бы Финляндии путь к заключению в случае необходимости сепаратного мира. Даже в том случае, если бы парламент утвердил такое соглашение, то это не привело бы к ликвидации антивоенного движения в Финляндии, а лишь обострило бы борьбу между противниками и сторонниками продолжения войны. Это ухудшило бы внешнеполитическое положение страны. Тогда в мировой прессе Финляндия снова изображалась бы как германский сателлит. ${ }^{49}$

Таким образом, после Сталинграда финское правительство сумело сохранить за собой самостоятельность в решении вопроса о заключении мира с противниками Германии. Последующие мирные зондажи оно вело, не ставя о них заранее в известность Берлин.

После Сталинградской битвы резко упал престиж германского вермахта в Финляндии. В начале июня 1943 г. в фринских газетах были опубликованы комментарии к одному из выступлений по радио немецкого военного обозревателя генерала К. Дитмара, в котором он, анализируя последние события на советско-германском фрронте, заявил: «Качества и тактики недостаточно для победы над Советами. Масса может быть побеждена только массой». Приводя эту фрразу, фринские газеты отмечали, что, оказывается, «тактика, которая применялась до сих пор на Востоке немцами, была совершенно ошибочной» и недвусмысленно выражали сомнение в способности Германии выиграть войну. В Германии это было расценено как попытка финской прессы «похоронить доверие к германскому вермахту в Финляндии». ${ }^{50}$ На самом деле там никакого доверия к германской армии уже давно не было. Еще 8 марта 1943 г. германский военный атташе в Хельсинки полковник Х. Кичман заявил: «Со времени Сталинграда и т.д. существенно ухудшилось настроение фриннов по отношению к Германии. Финское правительство больше не верит в германскую победу. Особенно пессимистичный настрой в фринской ставке Маннергейма». ${ }^{51}$

Заявление Линкомиеса о намерении продолжать войну шло в разрез с позицией США, но оно не повлекло за собой разрыва американо-финляндских отношений. Финское правительство весной и летом 1943 г. делало все, как отмечали следившие за ним немецкие военачальники, чтобы «держать дверь открытой в Америку». По инициативе сотрудников финского министерства иностранных дел 31 июля в Хельсинки было образовано «Финляндско-Американское общество», первым председателем которого стал Э. Эркко, владелец независимой газеты «Хелсингин Саномат». Официально это общество провозгласило себя культурной организацией, но на деле оно занялось политикой. Оно стремилось улучшить отношение фриннов к США и создать более позитивное отношение американцев к Финляндии в расчете на то, что благодаря этому США окажут Финляндии поддержку в создании наиболее благоприятных для нее условий выхода из войны против СССР и Великобритании. ${ }^{52}$

После поражения немецких войск в битве под Курском и высадки войск западных союзников в Италии в Финляндии резко возросли антивоенные настроения. 20 августа 1943 г. группа общественных деятелей, в основном депутатов парламента, в переданном президенту Рюти послании настаивала на вступлении в мирные переговоры со странами антигитлеровской коалиции. ${ }^{53}$ Эта группа опиралась на широкую поддержку среди различных слоев финского населения. Кроме того, в начале сентября лидер Социал-демократической партии Финляндии сделал заявление, в котором признавалось, что Финляндия должна исходить из того фракта, что «в будущем она будет жить как сосед сильной Советской России», что если бы Финляндия была гарантирована от внешней угрозы, то она немедленно приступила бы к «нормализации» фринляндско-советских отношений. Таннер далее утверждал, что «если Россия имеет 
намерение урегулировать отношения мирным путем, то это всегда найдет отклик в Финляндии». ${ }^{54}$

27 сентября Блюхер явился к Рамсаю и выразил свое удивление тем, что Таннер никогда ранее не делал заявлений такого рода, высказав опасение, что оно будет воспринято в Москве как приглашение финского правительства к началу мирных переговоров. Рамсай заверил его в том, что Таннер сделал заявление не как член правительства, хотя тот занимал в нем пост одного из министров, а как лидер социал-демократической партии лишь в «педагогических целях». Рамсай убеждал фринского посланника также не верить слухам о намерении финского правительства вступить в мирные переговоры с СССР ${ }^{55}$ Однако развеять подозрения Блюхера было уже невозможно. Они еще более усилились после того, как финское правительство отказалось выполнить просьбу Гитлера от 14 октября 1943 г. признать так называемую «Республику Сало», которая была создана по приказу из Берлина на оккупированной немецкими войсками части Апеннинского полуострова.

К тому времени и немецкому командованию было уже ясно, что оно не может более рассчитывать на активное участие финнов в войне против СССР. В этом его убедило сообщение начальника отдела внешних сношений генерального штаба сухопутных войск полковника К. Шухерта о впечатлениях, которые он вынес из поездке в Финляндию в конце октября 1944 г. Шухерт писал: «Страна гораздо больше настроена на мир, нежели на войну. Если бы представилась возможность выйти из войны, то она ею воспользовалась бы». ${ }^{56}$ Представители высшего и среднего командного состава финской армии в разговорах с ним уже не упоминали о фринляндско-германском «братстве по оружию» и не скрывали свою готовность поддержать свое правительство в поиске подходящих путей выхода из войны, правда, оговариваясь, что этот шаг будет предпринят с согласия германского военного командования. ${ }^{57}$

Советское правительство, учтя рост антивоенных настроений в Финляндии, в конце ноября 1943 г. через нейтральную Швецию предложило фринскому правительству направить в Москву делегацию для ведения переговоров о мире. Однако фринское правительство, выяснив, что в ходе этих переговоров советское правительство намерено настаивать на возобновлении действия Московского мирного договора от 12 марта 1940 г., в декабре отклонило советское предложение. ${ }^{58}$

Между тем, на Тегеранской конференции глав правительств СССР, США и Англии (28 ноября-1 декабря 1943 г.) по предложению президента США Ф. Рузвельта был обсужден вопрос о выводе Финляндии из войны. Главным итогом беседы явилось одобрение Ф. Рузвельтом и английским премьер-министром У. Черчиллем требования СССР о восстановлении советско-финляндского мирного договора 1940 г., но с одной поправкой. Было принято совместное решение, что СССР откажется от аренды полуострова Ханко, который должен быть демилитаризован, но в обмен на отказ от размещения там военно-морской базы, вернет себе область Петсамо (Печенга), которую советское правительство добровольно уступило Финляндии при заключении с нею Тартуского мирного договора от 14 ноября 1920 г.59

14 января 1944 г. войска Ленинградского и Волховского фронтов во взаимодействии со 2-м Прибалтийским фронтом перешли в наступление. Они прорвали оборону группы армий «Север» под Ленинградом и Новгородом и к концу месяца полностью освободили Ленинград от немецкой блокады, а в следующем месяце очистили от противника всю Ленинградскую область и вступили на территорию Эстонии. Отступление группы армий «Север» привело к тому, что финские войска, занимавшие позиции севернее Ленинграда, утратили стратегическое взаимодействие с немецкими войсками в Прибалтике. Возникли благоприятные предпосылки для развертывания наступления советских войск с целью разгрома финнов, захвативших Карельский перешеек и почти всю советскую Карелию.

Рузвельт в Тегеране обещал Сталину повлиять на фриннов с тем, чтобы они пошли на переговоры с Москвой. Обещание было выполнено. 31 января 1944 г. правительство США направило фринскому правительству меморандум. В нем указывалось, что если Финляндия заинтересована в поддержании дипломатических отношений с США, то она должна не только прекратить сотрудничество с Германией и добиться вывода немецких войск со своей территории, но и выйти из войны против Великобритании и СССР. В меморандуме содержалось предупреждение о том, что чем дольше 
Финляндия будет сотрудничать с Германией, тем хуже для нее будут условия мира. ${ }^{60}$

6 фревраля фринское правительство решило вступить в мирные переговоры с СССР. Это решение, как впоследствии президент Рюти заявил германскому посланнику, было принято под влиянием не американского меморандума, а успешного наступления советских войск против группы армий «Север» под Ленинградом. ${ }^{61}$

12 февраля по поручению финского правительства для установления контактов с советским полпредом в Швеции А.М. Коллонтай в Стокгольм прибыл государственный советник Ю. Паасикиви. С Коллонтай он встречался и вел переговоры 16, 19 и 21 февраля. Через нее он получил согласие советского правительства продолжить переговоры с Финляндией при условии, что она примет ряд следующих минимальных условий: разрыв отношений с Германией и интернирование находящихся в Финляндии немецких войск; восстановление советско-финляндского мирного договора 1940 г. и отвод фринских войск на установленную этим договором границу; немедленное возвращение на родину советских военнопленных и мирных граждан, содержащихся в концлагерях или используемых фриннами на работах. ${ }^{62}$ В Москве предполагалось обсудить вопросы: о частичной или полной демобилизации фринской армии; о возмещении Финляндией Советскому Союзу причиненного ущерба; о возвращении России области Петсамо. В конце февраля советские условия были опубликованы в шведской, а в начале марта в советской прессе.

Правительство Финляндии решило, что советские условия для него неприемлемы, но контакты с СССР нужно продолжить. Это решение 29 февраля одобрил фринский парламент. 8 марта фринское правительство сообщило советскому правительству о готовности начать переговоры, не высказав при этом своего негативного отношения к выдвинутым СССР условиям. 26 марта Паасикиви и бывший министр иностранных дел Финляндии К. Энкель инкогнито прибыли в Москву. Их принял советский министр иностранных дел В.М. Молотов. Переговоры состоялись 27 и 29 марта 1944г. Молотов настаивал, чтобы в дополнение к изложенным ранее минимальным условиям фринны взяли на себя обязательство осуществить поэтапное сокращение финских вооруженных сил до уровня мирного времени, возместить причиненный ущерб Советскому Союзу в размере 600 миллионов американских долларов, а также вернуть Советскому Союзу область Петсамо. ${ }^{63}$

Советское руководство нигде не ставило вопроса об оккупации Финляндии. Однако ее правительство и парламент 18 апреля 1944 г. объявили об отказе принять советские мирные условия, так как они якобы ставят под угрозу существование Финляндии как самостоятельного государства. Подлинная причина отказа, однако, заключалась в том, что вермахт в начале 1944 г. все еще оставался в Прибалтике достаточно мощным военным фрактором. В конце фревраля командованию группы армий «Север» удалось временно стабилизировать оборону на своем участке фрронта в Эстонии. На территории Финляндии находилась сильная группировка немецких войск. Не было никаких гарантий, что в случае попытки выйти из войны Финляндия не окажется под угрозой оккупации немецкими войсками. Кроме того, немецкий посол в Хельсинки В. Блюхер, следуя указаниям из Берлина, с начала 1944 г. постоянно оказывал сильное психологическое давление на фринское руководство с тем, чтобы воспрепятствовать его выходу из войны. Однако финны проявляли все меньше желания посвящать германское правительство в свои внешнеполитические планы.

Начальник отдела «Север» германского МИД В. Грундгер 11марта 1944 г. на основе донесений Блюхера подготовил документ, в котором содержался перечень попыток фринского министра иностранных дел Рамсая в феврале-марте 1944 г. воспрепятствовать вмешательству германского посланника в Хельсинки Блюхера в события, имевшие отношение к вопросу о выходе из войны Финляндии. ${ }^{64}$ Рамсай скрывал от Блюхера содержание американского меморандума от 31 января 1944г. до 10 февраля, даже после того, как этот документ 8 фревраля был обнародован американской прессой. 11 февраля он отрицал намерение своего правительства получить сведения об условиях, на которых СССР мог бы пойти на заключение мира с Финляндией, хотя именно с этой целью оно 12февраля направило в Стокгольм Паасикиви. 13 февраля, когда Блюхер узнал о прибытии Паасикиви в Стокгольм, Рамсай официально заверил Блюхера, что Паасикиви прибыл туда по «собственной инициативе» без поручений от правительства. 14 фревраля Рамсай снова утверждал, что фринское пра- 
вительство якобы не хочет устанавливать контакт с советским правительством. 16 марта из советской прессы Блюхеру стало известно, что цель визита Паасикиви заключается в том, чтобы завязать фринляндско-советские мирные переговоры. Рамсай же пытался убедить его, что это всего-навсего дезинформация. 18 февраля Рамсай снова заявил, что Паасикиви перед поездкой не получал никаких поручений от правительства. 25 февраля, когда стало известно о возвращении Паасикиви в Хельсинки, Рамсай сказал Блюхеру, что финское правительство не получило от него никакой инфрормации о советских мирных условиях. На самом деле эти условия в то время уже рассматривались финскими руководителями. 1 марта Рамсай в разговоре с Блюхером снова заявил о якобы непричастности фринского правительства к поездке Паасикиви в Стокгольм. К тому времени Блюхеру стало известно, что фринский парламент 29 февраля тайно собирался для обсуждения какого-то вопроса. Его попытка выяснить у Рамсая цель этого собрания не увенчалась успехом. Лишь 2 марта Рамсай, наконец-то, сообщил Блюхеру, что Паасикиви получил через Коллонтай советские мирные условия, но при этом снова утверждал, тот сделал это по собственной инициативе, а не по поручению правительства. Блюхер спросил, не собирается ли фринское руководство все же вступить в переговоры с советским правительством. Рамсай ответил, что этот вопрос обсуждается, но решение по нему еще не принято.

Дальнейшие сведения из Хельсинки «о финляндско-русском зондаже», по мнению германского МИД, «стали приобретать все более гротескный характер». Там уже не верили ни одному слову Рамсая, даже в том случае, если он говорил правду. 7 марта Рамсай сообщил Блюхеру, что фринское правительство еще не ответило на предложение советского правительства вступить в переговоры. Так оно и было. Но 8 марта в донесении в Берлин Блюхер опроверг Рамсая, так как из «тайного источника» ему стало якобы известно, что ответ финского правительства советскому правительству уже готов и сегодня отправлен в Москву. 10 марта Рамсай отказался ознакомить Блюхера с ответом советскому правительству под предлогом того, что ему пока неизвестно, дошел ли этот ответ до советского правительства. На основе всех этих фрактов в Берлине был сделан вывод, что «финское правительство вступило в переговоры с советским правительством по вопросам, затрагивающим непосредственно германские интересы, не проинформировав об этом детально и своевременно германское правительство». ${ }^{65}$

В фреврале Блюхер в разговорах с Рамсаем угрожал, что если Финляндия заключит с Советским Союзом мир или перемирие, то гитлеровское правительство будет рассматривать ее как предательницу и предпримет вытекающие из такой оценки меры. Представитель германского штаба связи в ставке Маннергейма генерал В. Эрфурт 28 марта заявил начальнику генерального штаба финских вооруженных сил генералу Э. Хейнриксу, что если Финляндия попытается выйти из войны на стороне Германии, то она будет оккупирована так же, как это было сделано немецкими войсками в Венгрии 19 марта 1944 г.66 Это были не пустые угрозы. К тому времени германскими военными штабами были уже подготовлены планы трех операций против Финляндии. С октября 1943 г. велась подготовка к операции под условным названием «Береза». Цель этой операции заключалась в захвате Северной Финляндии, где велись добыча и переработка никелевой руды, необходимой для фрунццинирования германской военной экономики. В феврале 1944 г. были разработаны еще два плана. Один из них - операция «Пихта Запад» - предусматривал оккупацию Аландских островов, а другой - операция «Пихта Восток» - острова Суурсари. ${ }^{67}$

К Финляндии были применены и экономические санкции. Риббентроп 3 апреля запретил поставку ей из Германии зерна, железа, каменного угля, минеральных удобрений и промышленных товаров широкого потребления. Через два дня немецкое командование отказалось удовлетворить просьбу финского военного командования поставить ему крупную партию артиллерийских орудий и противотанковых пушек. 18 апреля Гитлер одобрил это решение. ${ }^{68}$

Принятые немецким руководством репрессивные меры в отношении Финляндии оказались достаточны, чтобы заставить ее руководство продолжать войну. 12 мая Маннергейм направил Гитлеру письмо с просьбой возобновить поставки немецкого оружия для фринской армии. Гитлер отказался удовлетворить эту просьбу до тех пор, пока у него не появится уверенность в том, что Финляндия отказалась от поиска путей выхода из войны. ${ }^{69}$ 
Советское руководство весной 1944 г. убедилось в том, что правящая верхушка Финляндии все еще не готова пойти на разрыв с Германией. Поэтому в Москве было принято решение возобновить наступление с целью освобождения захваченной фринскими войска советской территории и вывода Финляндии из войны.

10-20 июня войска Ленинградского фронта провели Выборгскую операцию. Они отбросили финнов от Ленинграда на север на 110-130 км. 21 июня - 9 августа войска Карельского фронта провели Свирско-Петрозаводскую операцию, в ходе которой 28 июня был освобожден Петрозаводск, а затем и почти вся оккупированная ранее фриннами территория советской Карелии. Успех этих операций предопределил выход Финляндии из войны.

После начала Выборгской операции Ленинградского фронта Гитлер снял запрет на поставку в Финляндию немецкого вооружения. 19 июня, когда советские войска уже продвинулись к предместьям Выборга, финское военное командование обратилось к Гитлеру с просьбой предоставить в его распоряжение шесть немецких дивизий. Эту просьбу немецкое командование не выполнило из-за тяжелого положения вермахта на советско-германском фронте. 20 июня, в тот день, когда советские войска уже освободили Выборг, оно смогло передать финскому командованию лишь одну дивизию и бригаду штурмовых орудий из группы армий «Север» и одну эскадрилью самолетов из состава немецкой группировки, находившейся на севере Финляндии. ${ }^{70}$

На более значительную военную помощь со стороны Германии фринское руководство не могло рассчитывать. Поэтому 22 июня оно через министерство иностранных дел Швеции обратилось к советскому правительству просьбой о возобновлении мирных переговоров. В этот же день в Хельсинки прибыл министр иностранных дел Германии И. Риббентроп. Он в ультимативной форме потребовал от президента Финляндии Р. Рюти немедленно подписать германо-финляндское соглашение, в котором было бы зафиксировано обязательство Финляндии не заключать с СССР сепаратного мира или перемирия. ${ }^{71} 23$ июня В.М. Молотов в ответ на финское предложение выразил согласие принять фринскую делегацию в Москве для ведения переговоров о мире, но лишь после того, как финское правительство официально заявит, что «Финляндия капитулирует и просит мира у СССР». ${ }^{72}$ Этот ответ финская правящая верхушка расценила как требование о безоговорочной капитуляции Финляндии. Советский посол в Швеции А.М. Коллонтай во время передачи ответа Молотова и на следующий день разъяснила финнам, что в нем речь идет не о безоговорочной капитуляции, а лишь о прекращении военных действий на советско-финляндском фронте в качестве условия, при котором СССР будет согласен на ведение мирных переговоров. ${ }^{73}$ Но руководство Финляндии осталось при своем мнении и не дало никакого ответа на предложение Молотова начать переговоры в Москве. В то же время, оно не хотело заключать германо-фринляндский договор, который лишил бы Финляндию возможности выйти из войны без согласия на то Германии. Рюти принял компромиссное решение. 26 июня он от собственного имени направил Гитлеру письмо, в котором обещал, что не заключит мир с Советским Союзом и не допустит, чтобы назначенное им правительство вело переговоры с СССР о мире или перемирии. ${ }^{74}$

Отказ Финляндии использовать возможность порвать с Германией вызвал большое недовольство в Вашингтоне. В конце июня США разорвали дипломатические отношения с Финляндией. ${ }^{75}$

Рюти заранее знал, что в сложившейся тогда ситуации парламент не одобрит его обещания Гитлеру. 1 августа он был вынужден оставить свой пост. Парламент, в свою очередь, 5 августа избрал новой главой государства маршала Маннергейма. Тот взял курс на прекращение войны против СССР. 25 августа сформированное им новое финское правительство обратилось к советскому правительству с просьбой направить в Москву для ведения мирных переговоров финскую делегацию. 29 августа советское правительство дало согласие принять финскую делегацию в Москве при условии, что финское правительство публично заявит о разрыве отношений с Германией и предъявит ей требование о выводе ее войск из Финляндии в течение двух недель, не позже 15 сентября. ${ }^{76}$

1 сентября Маннергейм направил в Москву предложение, чтобы Финляндия сама провела в жизнь добровольную эвакуацию или интернирование немецких войск в южной части Финляндии, но при условии, что будут прекращены военные действия 
между финскими и советскими войсками. На следующий день он уведомил Гитлера о решении Финляндии выйти из войны. В тот же день вечером новый премьер-министр Финляндии А. Хакцель по радио объявил о вступлении своего правительства в мирные переговоры с антигитлеровской коалицией. Но, как пишут некоторые фринские историки, он в этом выступлении якобы случайно пропустил абзац, в котором сообщалось о разрыве Финляндией отношений с Германией. ${ }^{77}$

3 сентября советское правительство в ответе на предложение Маннергейма указало, что оно не возражает против прекращения военных действий, но лишь после того, как финское руководство выполнит предварительное условие, т.е. публично заявит о том, что оно разрывает отношения с Германией и требует вывода ее войск из Финляндии до 15 сентября.

Рано утром 4 сентября фринляндское телеграфное агентство, наконец-то, объявило, что финское правительство разорвало отношения с Германией и потребовало, чтобы она вывела ее войска из Финляндии до 15 сентября. Финские вооруженные силы в тот же утро в 8.00 получили приказ прекратить военные действия. Ровно через 24 часа войска Ленинградского и Карельского фрронтов по приказу Ставки Верховного Главнокомандования также прекратили военные действия. ${ }^{78}$

7 сентября фринская делегация во главе с Хацкелем вылетела в Москву. Однако переговоры начались только через неделю. За это время предъявляемые финнам условия были согласованы с Великобританией. 14 сентября состоялась первая встреча советской делегации с финской делегацией. За два часа до ее начала неожиданно тяжело заболел Хацкель. Временно финскую делегацию возглавил генерал Р. Вальден. Финнам был вручен проект соглашения о перемирии. 16 сентября в Москву прибыл министр иностранных дел К. Энкель и возглавил фринскую делегацию. 19 сентября состоялось подписание соглашения о перемирии СССР и Великобританией, с одной стороны, и Финляндией - с другой. От имени советского и британского правительства его подписал генерал-полковник А.А. Жданов. Согласно условиям перемирия, Финляндия обязывалась отвести свои войска за линию советско-фринляндской границы 1940 г. и разоружить все оставшиеся после 15 сентября на ее территории германские вооруженные силы. Их личный состав надлежало передать советскому главнокомандованию в качестве военнопленных. Восстанавливалось действие советско-финнляндского мирного договора 12 марта 1940 г. Кроме того, Финляндия обязывалась вернуть Советскому Союзу область Петсамо (Печенга). Советский Союз отказался от своих прав на аренду полуострова Ханко, а Финляндия обязывалась предоставить Советскому Союзу на правах аренды территорию и водные пространства для создания советской военноморской базы в районе Порккала-Удд. Соглашением было предусмотрено возмещение Финляндией ущерба, нанесенного Советскому Союзу, в размере 300 млн американских долларов. Контроль за выполнением Финляндией соглашения о перемирии был возложен на союзную контрольную комиссию. ${ }^{79}$

Между тем, Гитлер, получив от Маннергейма 2 сентября сообщение об отказе от дальнейшего фринляндско-германского военного сотрудничества, был вынужден отдать приказ немецким войскам в Финляндии начать отход из южных районов страны на север с целью захвата области Петсамо, откуда Германия получала никелевую руду. Позиции Германии на Балтике существенно ослабли. В связи с этим штаб националсоциалистического руководства группы армий «Север» 4 сентября 1944 г. направил в войска Нарвского укрепрайона следующее обращение: «На основании различных сообщений можно с уверенностью ожидать, что Финляндия выйдет из совместного европейского фронта борьбы и сложит оружие на условиях, выдвинутых Советским Союзом. Снова страна пала жертвой британского лицемерия и американского гангстерства и в результате позорного предательства выдана большевикам. Опять слабый парламентский режим проявил свою неспособность управлять народом. Потрясенный этим немецкий народ смотрит как смелый, ценный в расовом отношении финский народ, который в его героической борьбе получал большую военную и экономическую помощь от рейха, преданный и обманутый идет навстречу своей верной гибели. Для немецких солдат это событие является лишь подтверждением факта сотрудничества марксистско-интернационалистических держав с целью поддержать большевистское стремление к господству, а также подтверждением необходимости еще ожесточеннее вместе с родиной, тесно сплотившейся вокруг фюрера, отразить 
натиск азиатских степных волков, а затем их уничтожить. В Финляндии также имеются люди, которые в душе остались верны нашему делу и являются заклятыми врагами большевизма. Многолетняя героическая борьба фринских солдат не осталась напрасной. Рейх, который со времени первых переговоров Финляндии с Советским Союзом в марте 1944 г. учитывал возможность ее выхода из войны европейского оборонительного фрронта, приступил к подготовке необходимых мер безопасности. Солдат Северного фронта будет и дальше смело и верно, как приказал фюрер, защищать балтийское побережье». 80

Отказ Финляндии от военного сотрудничества с Германией существенно способствовал активизации боевых действий советского флота в Балтийском море. В связи с этим, главное командование германских ВМС в ночь на 15 сентября предприняло попытку осуществить захват финского острова Суурсари. В случае успеха этой операции оно рассчитывало создать там военно-морскую базу, с которой можно было бы блокировать выход советских кораблей их Финского залива. Однако эта попытка потерпела крах. Войска немецкой группировки, высадившейся на остров, сразу попали под прицельный огонь финских береговых батарей. На рассвете при поддержке авиации Балтийского Краснознаменного флота финский гарнизон разгромил противника. 153 немца были убиты и 1231 взяты в плен. ${ }^{81}$

В конце сентября-начале октября фринская армия приступила к изгнанию 200 тысячной группировки немецких войск со своей территории. Началась так называемая Лапландская война между Финляндией и Германией, продолжавшаяся до апреля 1945 г. В ходе этой войны Финляндия вынудила немцев отступить на территорию оккупированной ими соседней Норвегии, потеряв в ходе боев примерно 1 тыс. человек убитыми и пропавшими без вести и 3 тыс. ранеными. ${ }^{82}$

За время отступления из Финляндии немецкие войска применяли тактику «выжженной земли». Они разрушили 1060 крупных, в том числе железнодорожных, мостов, 3426 малых мостов и туннелей, полностью или частично уничтожили 725 железнодорожных путей, разрушили 16 аэродромов, затопили два парохода и 1000 мелких судов, уничтожили одну крупную ГЭС и многие другие фринские промышленные предприятия, а также все собственные военные сооружения, заложили около 100 тыс. мин, сожгли и разрушили тысячи жилых и общественных зданий. Нанесенный Финляндии ущерб превышал 120 млн американских долларов. Таков был итог так называемого фринляндско-германского «братства по оружию». ${ }^{83}$

В конце марта 1945 г. финское правительство официально заявило, что с 15 сентября 1944 г. Финляндия находилась в состоянии войны с Германией. За это время финские войска взяли в плен 2,5 тыс. немецких солдат и офицеров, которые после войны были переданы в СССР. ${ }^{84}$

10 фревраля 1947 г. в Париже состоялось подписание мирного договора между антигитлеровской коалицией и Финляндией. После ратификации 15 сентября того же года правительствами СССР, США, Великобритании и Франции договор вступил в силу. Согласно договору, границы Финляндии устанавливались в пределах, существовавших на 1 января 1941 г. Кроме того, Финляндия подтвердила возвращение Советскому Союзу области Петсамо (Печенга) и обязательство выплатить $300 \mathrm{млн} \mathrm{американских}$ долларов за причиненный ущерб. За СССР оставалось право на аренду района Порккала-Удд для создания военно-морской базы сроком на 50 лет. По договору Финляндия не могла иметь армию, численность которой превышала бы 34,4 тыс. человек. ${ }^{85}$

\section{ПРИМЕЧАНИЯ}

1998.C. 126.

1. Оссила О. и др. Политическая история Финляндии 1809-1995.М.,

2. Барышников Н.И. Блокада Ленинграда и Финляндия 1941-1944. Сант-Петербург-Хельсинки. 2002.С. 42.

3. Мировые войны XX века. Кн. 4. Вторая мировая война. Документы и материалы. М., 2002. С.123.

4. Menger M. Deutschland und Finnland im Zweiten Weltkrieg. B., 1988. S. 81.

5. Мировые войны XX века. Кн. 4. С. 126.

6. Menger M. Op. cit. S. 100-101.

7. Ibid. S. 144. 
8. Ibid. S. $126-127$.

9. Ibid. S. 103.

10. Ibidem.

11. Ibid. S. 106-107.

12. Ibid. S. 133.

13. Ibid. S 110-111.

14. Барышников Н.И. и др. Финляндия во второй мировой войне. Л., 1988. С. 153.

15. Там же; Барышников Н.И. Блокада Ленинграда...С. 41.

16. Барышников Н.И. и др. Указ соч. С. 158.

17. Menger M. Op. cit. S. 113-125.

18. Bundesarchiv. Militäriches Zwischenarchiv. Potsdam. WF/01/13767. BI. 330—332.

19. Menger M. Op. cit. S. 134.

20. История второй мировой войны 1939-1945. М., 1975. Т. 4. С. 64.

21. Юссила О. и др. Указ. соч. С. 206; Das Deutsche Reich und der Zweite Weltkrieg. Stuttgart, 1984. Bd.4. S. 841; Menger M. Op. cit. S. 138.

22. Menger M. Op. cit. S. 143-144.

23. В семье единой. Национальная политика большевиков и ее осуществление на Северо-Западе России в 1920-е-1950-е годы. Петрозаводск, 1958. С. 232233, 238.

24. Там же. С. 234.

25. Там же.

26. Барышников Н.И. Указ. соч. С. 81.

27. Das Deutsche Reich und der Zweite Weltkrieg. Bd. 4. S. 854-855.

28. Барышников Н.И. Указ. соч. С. 154.

29. Там же. С. 154-155.

30. Bundesarchiv. Militärisches Zwischenarchiv Potsdam. WF-01/13767. BI. 330-332.

31. Барышников Н.И. и др. Указ. соч. С. 154.

32. Bundesarchiv. Militärisches Zwischenarchiv Potsdam. WF-01/16783. BI. 275.

33. Барышников Н.И. Указ. соч. С. 155-156.

34. Там же. С. 175-176, 183.

35. Deutschland im Zweiten Weltkrieg. B. 1979. Bd. 3. S. 425.

36. Bundesarchiv. Abtelung Potsdam. 09.01. A.A. № 61130. BI. 76-77.

37. Ibidem.

38. Маннергейм К.Г. Мемуары. Пер. с фин. М., 1999. С. 439-440.

39. Bundesarchiv. Abteilung Potsdam. 09.01 A.A. № 61130. BI. 77-78.

40. Bundesarchiv. Abteilung Potsdam. FA.A. Nr. 61130. BI. 58.

41. Ibid. Bl. 59-61.

42. Berry R.M. American Foreign Policy and the Finnish Exception. Ideological Preferences and Wartime Realities. Helsinki, 1987. H. 269—270.

43. Ibid. P. 272.

44. Expansionsrichtung Nordeuropa. Dokumente zur Nordeuropapolitik des faschistischen deutschen Imperialismus 1939 bis 1945. B. 1987. S. 150.

45. Bundesarchiv. Abteilung Potsdam. 09.01. A.A. № 61130. BI. 105.

46. Барышников и др. Указ. соч. С. 210.

47. Bundesarchiv. Militärisches Zwieschenarchiv. Potsdam.WF-01/16783. BI. 324.

48. Bundesarchiv. Abteilung Potsdam.09.01. № 61130. BI. 125-126.

49. Ibid. 09.01. A.A. Nr. 61130. BI. 144-145.

50. Budesarchiv. Militärisches Zwischenarchiv. Potsdam. WF-01/16783. BI. 114.

51. Menger M. Op. cit. S. 162-163.

52. Berry R.M. Op. cit. P. 307-311.

53. Юссила и др. Указ. Соч. С.211.

54. Bundesarchiv. Abteilung Potsdam. BI. 178-179.

55. Ibidem.

56. Bundesarchiv. Militärisches Zwischenarchiv. Potsdam. WF-01/13637. BI. 885.

57. Ibid. BI. 886-887.

58. Menger M. Op. cit. S. $167-168$.

59. Комаров А.А. Выход Финляндии из второй мировой войны. По материалам Архива внешней политики МИД России / Северная Европа. Проблемы истории. М., 
1998. С. 118; Юссила О. и др. Указ. Соч. С. 211; Berry R.M. Op. cit. Р. 356-359.

60. Berry R.M. Op. cit. P. 383-383.

61. Ibid. P. 386.

62. Комаров А.А. Указ. Соч. С. 119.

63. Там же. С. 120-123.

64. Bundesarhiv. Abteilung Potsdam. 09.01. A.A. Nr. 61130. BI. 205-208.

65. Ibid. S. 208.

66. Menger M. Op. cit. S. 188.

67. Expansionsrichtung Nordeuropa... S. 158-159; Menger M. Op. cit. S. 177-180.

68. Expansionsrichtung Nordeuropa... S. 177-178, 181-182.

69. Menger M. Op. cit. S. 191-193.

70. История второй мировой войны 1939-1945. М., 1978. Т. 9. С. 31; Menger M. Op. cit. S. 185.

71. Menger M. Op. cit. S. 200.

72. Комаров А.А. Указ. Соч. С. 125.

73. Menger M. Op. cit. S. 202.

74. Барышников Н.И. и др. Указ. соч. С. 255.

75. Berry R.M. Op. cit. P. 416.

76. Комаров А.А. Указ. соч. С. 126.

77. Юссила О. и др. Указ соч. С. 219.

78. Menger M. Op. cit. S. 223.

79. Комаров А.А. Указ. соч. С. 126-129.

80. Bundesarchiv. Miltärisches Zwischenarchiv. WF-03/12512. BI. 083.

81. История второй мировой войны 1939-1945. М., 1979.Т. 9. С. 36; Menger M. Op. cit. S. 238.

82. Menger M. Op. cit. S. 249.

83. Expansionsrichtung Nordeuropa... S. 200; История второй мировой войны 19391945. T. 9. C. 37.

84. Menger M. Op. cit. S. 249.

85. Международные отношения после второй мировой войны. М., 1962. Т. 1. C. $518,522-524$. 